\title{
GAMBARAN TINGKAT PENGETAHUAN KADER POSYANDU TENTANG PENULARAN HIV/AIDS DARI IBU KE ANAK DI DESA CILELES TAHUN 2017
}

\author{
Fardila Elba $^{1)}$, Merry Wijaya $^{1)}$, Farah Dina Nurfathia ${ }^{2)}$ \\ Email: fardilaelba@yahoo.com \\ ${ }^{1}$ Dapartemen Ilmu Kesehatan Masyarakat Fakultas Kedokteran, Universitas Padjadjaran \\ ${ }^{2}$ Program Studi Diploma IV Kebidanan Fakultas Kedokteran, Universitas Indonesia
}

\begin{abstract}
In Indonesia, in 2014 the total number of pregnant women was 5,192,427, only 5,167 (0.1\%) were tested for HIV. The HIV virus can be transmitted from HIV-infected mothers to their children during pregnancy, during labor and breastfeeding. HIV transmission from mother to child can actually be intervened with PMTCT. However, the coverage is still low at $8 \%$ in 2010. Basic level health services can be assisted by cadres in MCH services by motivating and supporting pregnant women by motivating pregnant women to test HIV / AIDS.

This study used a cross-sectional approach. The sample in this study was a Posyandu Cadre in Cileles Village. Sampling using total sampling technique with the number of samples that correspond to the inclusion and exclusion criteria as many as 53 respondents.

The research shows that the level of good knowledge is mostly in the age group of 20-35, the best knowledge is mostly at the junior high school level, and the best knowledge is mostly on cadres with a working period of 0-5 years.

Most respondents have sufficient knowledge about HIV / AIDS transmission from mother to child. Sufficient knowledge can be obtained from various sources, such as: mass media, books, and information obtained from health workers.
\end{abstract}

Keywords: AIDS, Age, Education Level, HIV, Length of cadre, Transmission, PPIA.

\section{PENDAHULUAN}

Menurut Pusat Data dan Informasi, Kementerian Kesehatan RI pada tahun 2013 ada ada 35 juta orang hidup dengan HIV di dunia diantaranya adalah 16 juta perempuan dan 3,2 juta anak berusaia <15 tahun. Di Indonesia pada tahun 2014 jumlah keseluruhan penderita HIV adalah 150.285 dan AIDS 55.799. Dari total keseluruhan ibu hamil di Indonesia sebanyak 5.192.427 hanya $5.167(0,1 \%)$ yang melakukan pemeriksaan HIV, dimana 1.306 ibu hamil (25\%) diantaranya positif menderita HIV. Virus HIV dapat ditularkan dari ibu yang terinfeksi HIV kepada anaknya selama kehamilan 5-
$10 \%$, saat persalinan $10-20 \%$ dan menyusui $5-20 \% .1,2$

Salah satu kasus penularan HIV dari ibu ke bayi atau dalam istilah lainnya Mother to Child HIV Transmission (MTCT) masih merupakan cara penularan yang cukup tinggi. Hingga saat ini kejadian penularan dari ibu ke anak sudah mencapai 2,6 persen dari seluruh kasus HIV/AIDS yang dilaporkan di Indonesia.

Dalam upaya pengendalian kasus HIV/AIDS di Indonesia khususnya dalam pencegahan penularan dari ibu dan anak, Pemerintah membuat program Pencegahan Penularan HIV dari Ibu ke Anak (PPIA) atau 
dikenal dengan Prevention of Mother To Child Transmission (PMTCT) karena penularan HIV dalam kasus ini sebenarnya dapat di intervensi dengan PPIA yang bertujuan untuk mengurangi jumlah kasus HIV baru, menurunkan angka kematian ibu dan bayi akibat HIV, juga meningkatkan kualitas hidup ibu hamil dan anak dengan HIV.2

Namun meskipun program PPIA telah dilaksanankan, cakupan layanan PPIA di Indonesia masih rendah. yaitu $10 \%$ di tahun 2004, meningkat menjadi $35 \%$ pada tahun 2007, 45\% di tahun 2008, dan menurun pada tahun 2010 yaitu $8 \%$ sehingga diperlukannya peningkatan cakupan pelayanan PPIA.2

Program PPIA dibentuk guna untuk mendeteksi dini penularan HIV/AIDS dari ibu ke bayi sehingga dapat dimulai pada jenjang pelayanan kesehatan yang dasar yaitu di Pusat Pelayanan Terpadu (Posyandu).3

Pada penyelenggaraan pelayanan kesehatan tingkat dasar dibantu peningkatan dan peran beserta fungsinya oleh seorang kader sebagai seorang yang berhubungan langsung dalam bermasyarakat. Kader mempunyai peranan sebagai seseorang yang dipercaya dalam masyarakat dan mengajak masyarakat mengenali betapa pentingnya kesehatan sehingga diperlukan untuk datang ke Posyandu guna memperoleh pelayanan kesehatan yang baik. ${ }^{4,5,6}$

\section{METODE PENELITIAN}

Penelitian ini menggunakan pendekatan cross-sectional. Sampel dalam penelitian ini adalah Kader Posyandu di Desa Cileles. Pengambilan sampel menggunakan teknik total sampling dengan jumlah sampel yang sesuai dengan kriteria inklusi dan eklusi sebanyak 53 responden. ${ }^{7}$

\section{HASIL DAN PEMBAHASAN}

Dari 53 responden yang diikutsertakan dalam analisis peneliti tampilkan dalam data karakteristik pada tabel di bawah ini:

Tabel 1 Karakteristik Responden Pengetahuan Kader tentang Manfaat PPIA di Desa Cileles

\begin{tabular}{lllc}
\hline Karakteristik & Kategori & f & \% \\
\hline Usia & 20-35 Tahun & 18 & 34 \\
& 36-45 Tahun & 20 & 37.8 \\
& $>45$ Tahun & 15 & 28.2 \\
\hline \multirow{3}{*}{ Pendidikan } & Tamat SD/sederajat & 15 & 28.2 \\
& Tamat SMP/sederajat & 21 & 39.6 \\
& Tamat SMA/sederajat & 15 & 28.2 \\
& > SMA & 2 & 4 \\
\hline \multirow{3}{*}{ Lama Menjadi } & 0-5 tahun & 27 & 51 \\
Kader & 6-10 Tahun & 9 & 17 \\
& 11-20 tahun & 13 & 24.5 \\
& $>20$ Tahun & 4 & 7.5 \\
\hline
\end{tabular}


Berdasarkan tabel di atas tampak usia responden antara 36 - 45 tahun dan yang 20 tahun tidak jauh berbeda, tetapi masih terdapat 15 responden yang berusia lebih dari 45 tahun. Dalam penelitian ini didapatkan lebih banyak responden yang lulusan SMP 21 responden (39.6\%) dibandingkan dengan responden yang, lulusan SD 15 responden (28.2\%) lulusan SMA 15 responden (28.2\%) dan lulusan perguruan tinggi 2 responden (4\%). Dilihat dari lama menjadi kader 27 responden $(51 \%)$ bekerja selama 0-5 tahun, 9 responden (17\%) 6-10 tahun, 13 responden (24.5\%) selama 10-20 tahun dan 4 responden (7.5\%) selama >20 tahun.

Hasil penelitian menunjukan bahwa sebagian besar responden memiliki pengetahuan yang cukup mengenai manfaat Program Pencegahan HIV/AIDS dari Ibu ke Anak. Pengetahuan yang cukup dapat diperoleh dari berbagai sumber, seperti: media massa (cetak dan elektronik), bukubuku, serta informasi yang didapat dari petugas kesehatan. Pengetahuan yang baik mengenai pengetahuan dalam upaya pencegahan penularah HIV/AIDS dari ibu ke anak diperoleh dari media massa maupun orang per orang namun masih terdapat banyak kader yang kurang memahami mengenai cara penularan dan cara pencegahan karena kurangnya informasi yang diperoleh tentang hal tersebut. Sebagian besar responden dalam penelitian ini mengatakan bahwa belum pernah menerima informasi mengenai Program Pencegahan Penularan HIV/AIDS dari Ibu ke Anak.
Tabel 2 Pengetahuan berdasarkan usia

\begin{tabular}{ccccccc}
\hline Usia & \multicolumn{7}{c}{$\begin{array}{l}\text { Pengetahuan } \\
\text { Baik } \\
\text { Kurang }\end{array}$} & \multicolumn{1}{l}{ fup } \\
& f & \% & f & \% & f & \\
\hline $20-35$ & 9 & 17 & 8 & 15 & 0 & 0 \\
$36-45$ & 11 & 20.8 & 8 & 15 & 2 & 3.8 \\
$>45$ & 7 & 13.4 & 8 & 15 & 0 & 0 \\
\hline Jumlah & 27 & 51.2 & 24 & 45 & 2 & 3.8 \\
\hline
\end{tabular}

Berdasarkan tabel di atas, responden yang memiliki tingkat pengetahuan baik paling banyak berada pada kelompok usia 36-45 tahun yaitu 11 responden (20.8\%), 24 dari 53 responden yang memiliki pengetahuan cukup (45\%), dan 2 dari 53 responden yang memiliki pengetahuan kurang (3.8\%).

Usia merupakan salah satu faktor yang mempengaruhi pengetahuan. Semakin bertambahnya usia seseorang maka akan terjadi peningkatan daya tangkap serta pola berpikir sehingga pengetahuan yang diperolehnya semakin baik. Namun meskipun usia merupakan salah satu faktor yang mempengaruhi pengetahuan karena semakin bertambahnya usia seseorang maka akan terjadi peningkatan daya tangkap serta pola berpikir sehingga pengetahuan yang diperolehnya semakin baik namun jika semakin berta, bahnya usia akan terjadi pula proses kemunduran organ yang dapat menimbulkan kepikunan jika semakin tua usia. $^{8}$ 
Tabel 3 Pengetahuan

Berdasarkan Tingkat

Pendidikan

\begin{tabular}{ccccccc}
\hline Tingkat & \multicolumn{5}{c}{ Pengetahuan } \\
& \multicolumn{2}{c}{ Baik } & \multicolumn{2}{c}{ Cukup } & \multicolumn{2}{c}{ Kurang } \\
Pendidikan & f & \% & & \% & f & \% \\
\hline SD & 6 & 11.1 & 8 & 15.1 & 1 & 1.9 \\
SMP & 12 & 22.2 & 9 & 17 & 0 & 0 \\
SMA & 7 & 13.1 & 7 & 13.1 & 1 & 1.9 \\
Peguruan Tinggi & 2 & 3.5 & 0 & 0 & 0 & 0 \\
\hline Jumlah & 27 & 50 & 24 & 46.2 & 2 & 3.8 \\
\hline
\end{tabular}

Berdasarkan tabel di atas, responden yang memiliki pengetahuan baik paling banyak berada pada tingkat pendidikan SMP sebanyak 27 responden (50\%), yang memiliki pengetahuan cukup paling banyak berada di tingkat pendidikan SMA.

Pada penelitian ini pengetahuan baik paling banyak berada pada tingkat pendidikan SMP. Menurut hasil penelitian Yuyun (2015) yang menyebutkan bahwa pengetahuan kader yang baik berada pada responden dengan tingkat pendidikan yang tinggi (SMA). Penelitian tersebut menyatakan semakin tinggi tingkat pendidikan seseorang maka makin mudah pula untuk menerima informasi sehingga makin banyak pula pengetahuan yang dimiliki.24 Hal tersebut tidak sesuai dengan hasil penelitian ini yang menunjukan bahwa responden yang memiliki pengetahuan baik sebagian besar berpendidikan SMP dan pengetahuan cukup paling banyak pada responden berpendidikan terakhir SMA. Meskipun tingkat pendidikan seseorang akan mempermudah proses penerimaan informasi dan nilai-nilai baru, tetapi belum tentu mempengaruhi tingkat pengetahuan karena pengetahuan dapat dipengaruhi oleh faktor lainnya seperti intelegensia, minat, umur, dan pekerjaan. ${ }^{9}$

\section{Tabel 4 Pengetahuan Berdasarkan} Lama Menjadi Kader

\begin{tabular}{ccccccc}
\hline Lama & \multicolumn{5}{c}{ Pengetahuan } \\
Menjadi & \multicolumn{2}{c}{ Baik } & \multicolumn{2}{c}{ Cukup } & \multicolumn{2}{c}{ Kurang } \\
\cline { 2 - 7 } $\begin{array}{c}\text { Kader } \\
\text { (Tahun) }\end{array}$ & f & \% & F & \% & f & \% \\
\hline $0-5$ & 14 & 26.4 & 11 & 20.8 & 2 & 3.8 \\
$6-10$ & 4 & 7.5 & 5 & 9.4 & 0 & 0 \\
$10-20$ & 7 & 13.2 & 5 & 9.4 & 0 & 0 \\
$>20$ & 2 & 3.8 & 3 & 5.7 & 0 & 0 \\
\hline Jumlah & 27 & 50.9 & 24 & 45.3 & 2 & 3.8 \\
\hline
\end{tabular}

Berdasarkan tabel diatas diketahui bahwa kader dengan kategori lama kerja 0-5 tahun sebanyak 27 orang, kategori lama kerja 6-10 tahun sebanyak 9 orang, kategori lama kerja 10-20 tahun sebanyak 12 orang dan kategori lama kerja >20 tahun sebanyak 5 orang.

Dari hasil penelitian tampak kader dengan masa kerja 0-5 tahun lebih banyak yang memiliki pengetahuan baik dari kader dengan lama kerja $>5$ tahun. Hal ini tidak selaras dengan dengan penelitian Indah (2014) karena tidak terdapat hubungan antara lama menjadi kader dengan pengetahuan yang dimiliki. Seperti yang diketahui bahwa kader berperan sebagai sukarela sehingga hal tersebut kadangkala membuat kader merasa tidak terlalu terikat dengan tugasnya. ${ }^{10}$ 


\section{KESIMPULAN}

Hasil penelitian menunjukan bahwa pengetahuan kader Posyandu tentang Penularan HIV/AIDS dari Ibu ke Anak di Desa Cileles berdasarka usia yang memiliki tingkat pengetahuan baik sebanyak 27 responden (50.9\%), pengetahuan cukup 24 responden $(45.3 \%)$ dan pengetahuan yang kurang sebanyak 2 responden (3.8\%).

Pengetahuan kader Posyandu tentang Penularan HIV/AIDS dari Ibu ke Anak di Desa Cileles berdasarkan tingkat pendidikan yang memiliki pengetahuan baik 6 responden pada tingkat SD (11,3\%), 12 responden pada tingkat SMP (22.6\%), 7 responden pada tingkat SMA (13.2\%), 2 responden pada tingkat pendidikan Perguruan Tinggi (3,8\%).

Pengetahuan kader Posyandu tentang Penularan HIV/AIDS dari Ibu ke Anak di Desa Cileles berdasarkan lama menjadi kader yang memiliki pengetahuan baik 14 responden $(51,9 \%)$ dengan masa kerja 0-5 tahun, 4 responden $(14.8 \%)$ dengan masa kerja 5-10 tahun, 7 responden (25.9\%) dengan masa kerja 10-20 tahun, dan 2 responden $(7.4 \%)$ dengan masa kerja lebih dari 20 tahun.

\section{REFERENSI}

1. KEMENKES. Pusat Data dan Informasi. Jakarta2014.

2. KEMENKES. Pencegahan Penularan Hiv dari Ibu Ke Anak. Jakarta 2011.

3. KEMENKES. Pedoman Umum Pengelolaan Posyandu. Jakarta2015.

4. Gandana. Buku Pegangan Kader Posyandu. Jawa Barat: Dinas Kesehatan; 2012.

5. Yurianto A. Buku Pegangan Kader. Jakarta: Kementerian Kesehatan; 2015.

6. Nursalam. Ilmu Kesehatan Anak. Jakarta: Salemba Medika; 2014.

7. Sulistyaningsih. Metodologi Penelitian Kebidanan: Kuantitatif-Kualitatif. Yogyakarta: Graha Ilmu; 2011.

8. Aldila N. Gambaran pengetahuan kader tentang MP-ASI berdasarkan usia di Probolinggo. 2015.

9. Setyorini Y. Hubungan tingkat pendidikan dan tingkat pengetahuan kader tentang PHBS di Kabupaten Boyolali. 2015.

10.Nurindah W. Faktor-faktor yang berhubungan dengan tingkat pengetahuan kader Kesehatan di Kabupaten Banyumas. Purwokerto: UNSOED; 2014. 